\title{
POST-TRANSITION POVERTY TRENDS BASED ON AN ALTERNATIVE DATA SOURCE
}

\author{
SERVAAS VAN DER BERG, MEGAN LOUW AND DEREK YU
}

\section{Stellenbosch Economic Working Papers: 08/07}

KEYWORDS: POVERTY, INEQUALITY, INCOME DISTRIBUTION ANALYSIS, SOUTH AFRICA JEL: D6, I32, I38

SERVAAS VAN DER BERG DEPARTMENT OF ECONOMICS UNIVERSITY OF STELLENBOSCH PRIVATE BAG X1, 7602 MATIELAND, SOUTH AFRICA E-MAIL: SVDB@SUN.AC.ZA
MEGAN LOUW DEPARTMENT OF ECONOMICS UNIVERSITY OF STELLENBOSCH PRIVATE BAG X1, 7602 MATIELAND, SOUTH AFRICA E-MAIL: MEGANL@SUN.AC.ZA
DEREK YU DEPARTMENT OF ECONOMICS UNIVERSITY OF STELLENBOSCH PRIVATE BAG X1, 7602 MATIELAND, SOUTH AFRICA E-MAIL: DEREKY@SUN.AC.ZA

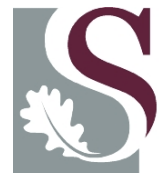

UNIVERSITEIT

A WORKING PAPER OF THE DEPARTMENT OF ECONOMICS AND THE BUREAU FOR ECONOMIC RESEARCH AT THE UNIVERSITY OF STELLENBOSCH 


\title{
POST-TRANSITION POVERTY TRENDS BASED ON AN ALTERNATIVE DATA SOURCE ${ }^{1}$
}

\author{
SERVAAS VAN DER BERG, MEGAN LOUW AND DEREK YU²
}

ABSTRACT

This paper analyses a previously unused source of data - the All Media and Product Survey (AMPS) - to arrive at alternative estimates of the post-transition poverty path. The motivations for using this non-official data source are twofold: concern over the comparability of the existing official post-transition datasets - the Income and Expenditure Survey (IES) and Population Census - and a desire to extend analysis of poverty trends beyond 2001 . While official data sources are generally preferred for purposes of poverty analysis, the IES and Census collect data at long (five or ten year) intervals, and additional years pass before these datasets become available to the public. The expenditure data contained in the General Household Survey is available annually, although data are captured in a small number of categories that are not very conducive to analysis at the lower end of the income distribution. Analysis on AMPS data confirms the large decline in poverty implied by an increase of R18 billion (in 2000 Rand) in social grant payments between 2000 and 2004. The direction of this trend is consistent with recent research findings based on more frequently analysed data sources, including the work done by Agüero, Carter and May (2005), Seekings (2006), and Meth (2006).

Keywords: Poverty, Inequality, Income distribution Analysis, South Africa JEL codes: D6, I32, I38
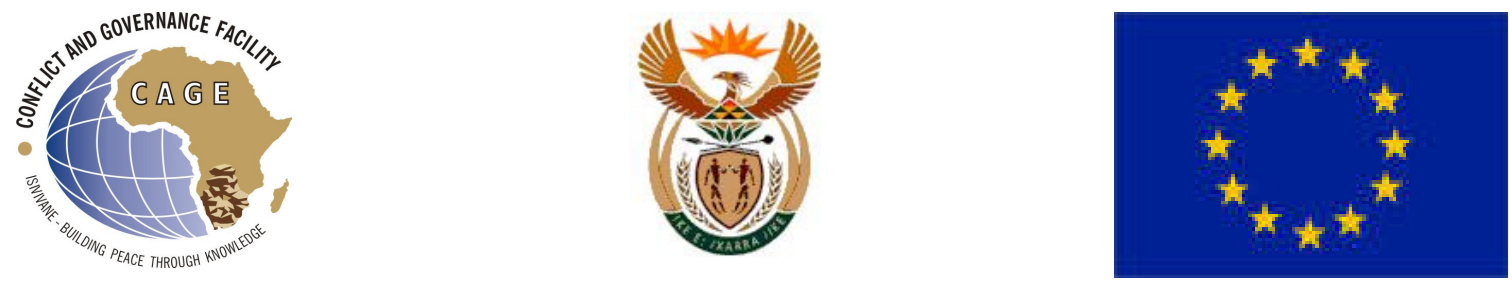

\footnotetext{
1 This document has been produced with the financial assistance of the European Union. The contents of this document are the sole responsibility of the Department of Economics at the University of Stellenbosch and can under no circumstances be regarded as reflecting the position of the European Union.

${ }^{2}$ Department of Economics, University of Stellenbosch.
} 


\section{POST-TRANSITION POVERTY TRENDS BASED ON AN ALTERNATIVE DATA SOURCE}

\section{INTRODUCTION}

This paper analyses a previously unused source of data - the All Media and Product Survey (AMPS) - to arrive at alternative estimates of the post-transition poverty path. The motivations for using this non-official data source are twofold: concern over the comparability of the existing official post-transition datasets - the Income and Expenditure Survey (IES) and Population Census - and a desire to extend analysis of poverty trends beyond the turn of the century. The AMPS surveys are conducted semi-annually or annually, allowing one both to gain an idea of the most recent movements in poverty rates and to identify "irregular" survey results that are out of line with the rest of the series. By contrast, the official household surveys that collect comprehensive income or expenditure data are conducted less frequently (generally every five years). Currently the post-transition versions of such datasets are only available for two years (1995 and 2000 in the case of the IES, 1996 and 2001 in the case of the Census). Since these datasets currently act as series endpoints, derived trends are heavily influenced by the quirks inherent in individual surveys. Furthermore, both data sources only become available with a considerable lag, removing the possibility of estimating up-to-date poverty trends from them.

The paper begins with a brief review of studies concerned with post-transition poverty trends in South Africa. It progresses to a discussion regarding the comparability of official datasets, before providing further information regarding AMPS survey design and reliability. AMPS-based distributional analysis is presented, showing a marked decline in poverty from 2002 onwards. Corroborating evidence is provided, including an IES2000-based scenario taking into account the rapid expansion in social grant payments during the second half of the post-transition decade.

\section{AN OVERVIEW OF POST-TRANSITION POVERTY TREND RESEARCH}

Recent poverty trend studies have analysed data from the 1995 and 2000 IES household surveys (together with the linked 1995 October Household Survey (OHS) and September 2000 LFS as well as income data from the Censuses conducted in 1996 and 2001. The majority of work suggests that poverty has become a greater problem since 1994.

Interestingly - given government's objection to claims that its first-term efforts to reduce poverty have failed (ANC Today 2003) - the first study to suggest that poverty had worsened since 1994 came in the form of an official report published in 2002 by Statistics South Africa (Stats SA). This report compared IES data sets for 1995 and 2000, and found that household incomes had declined since the transition, thus resulting in an increase in poverty. Findings on income inequality were less conclusive, with evidence of only a small increase in the Gini coefficient from 0.56 to 0.57 (Stats SA 2002). Other recent studies that corroborate Statistics South Africa's claims regarding the path of poverty include those by Hoogeveen and Özler (2006), Leibbrandt, Poswell, Naidoo, Welch and Woolard (2006), Leibbrandt, Levinsohn and McCrary (2005) and Meth and Dias (2004). 
Hoogeveen and Özler (2006) analysed the income distribution using the IES/OHS1995 and IES2000/LFS2000:2 (i.e. September 2000 LFS). They applied two poverty lines to household per capita expenditure, including the international $\$ 2$ a day poverty line (or R174 in 2000 prices) and a lower-bound "cost-of-basic-needs" poverty line of R322 per month in 2000 prices. The authors found evidence of an increase in the incidence of more extreme poverty between 1995 and 2000, with 2.3 million more living on less than 2.3 million a day by 2000 (Hoogeen \& Özler 2006: 87). However, they found that the proportion of South Africans living in more moderate poverty (i.e. on less than R322 per month) remained constant. In addition, their analysis showed that the depth and severity of poverty increased significantly for any poverty line up to R322 (Hoogeveen \& Özler 2006: 64). The rise in extreme poverty appears to due to rising poverty amongst blacks, since poverty at this level declined significantly amongst members of the only other group represented amongst the extremely poor, coloureds. Disaggregating by geography, the greatest increases in poverty appeared to be concentrated in rural provinces containing former homelands as well as in Gauteng (Hoogeveen \& Özler 2006: 65-69).

The phenomena underlying these figures are likely to be weakening access to income in rural areas as well as ongoing high unemployment rates in the metropolitan areas that draw jobseekers. Indeed, in an earlier paper based on the same data, Hoogeveen and Özler argued that the rates of return to education increased between 1995 and 2000 only for highly educated individuals in urban areas, of which blacks constitute a relatively small proportion (Hoogeveen \& Özler 2004).

Hoogeveen and Özler (2006) also report that inequality increased over the period, a finding that is predominantly attributed to an observed increase in the size of the increasingly highly unequal black population. The observed change in the Gini coefficient is small - i.e. 0.56 to 0.58 (Hoogeveen \& Özler 2006: 72) - although this is attributed to the Gini coefficient being most sensitive to changes in the middle of the distribution. Employing an inequality measure that is sensitive to changes at the lower end of the distribution, namely the mean logarithmic deviation, Hoogeveen and Özler (2006: 73) find evidence of a greater rise in inequality.

Leibbrandt, Levinsohn and McCrary (2005) utilised the same datasets as Hoogeveen and Özler (2006). However, they focused on individual incomes (based on the sample of individuals aged 18 and older) rather than on household per capita incomes or expenditures, as other studies do. Leibbrandt et al. (2005) found that the distribution of real income shifted to the left over the period, resulting in a drop in real income of $40 \%$ for income earners and thus an increase in poverty (Leibbrandt et al. 2005: 4). The authors noted that this large fall in income was inconsistent with trends in the national accounts, although they did not discuss the issue further (Leibbrandt et al. 2005: 8). In the same vein as Hoogeveen and Özler (2004), they suggest that the main reason for the observed shift in the distribution is a change in the returns to endowments; in particular, their research adduces evidence of falling returns to education for blacks, which contrasts with rising returns to education for whites. One explanation put forward for this finding is that whites possess higher levels of education, and have consequently reaped many of the benefits associated with skill-biased technical change. Furthermore it might be too early to expect affirmative action to have had much of an influence on racial restructuring of the labour 
market, particularly given the low rate of job creation. Youth and blacks appear to have borne the heaviest burden of income losses (Leibbrandt et al. 2005: 35-37).

Section 3 of this paper argues that the IES1995 and 2000 datasets are particularly problematic for purposes of comparing the income distribution across years. Accordingly, attention turns to studies that do not rely on the IES datasets for inference. Leibbrandt, Poswell, Naidoo, Welch and Woolard (2006) analysed data from 10\% samples of the 1996 and 2001 Censuses, focusing on both income and access poverty. These authors defined poverty in terms of two poverty lines: the international $\$ 2$ a day line, and the level at which Statistics South Africa first set the poverty line in its poverty-mapping work: R250 per month in 1996 Rand. Applying these poverty lines to household per capita incomes, they found that income poverty increased between 1996 and 2001, continuing an earlier trend noted by Whiteford and Van Seventer (2000). In contrast to Hoogeveen and Özler's (2004) claim, however, Leibbrandt et al. (2006: 106) argue that extreme poverty (defined in terms of the $\$ 2$ a day line) increased less substantially than moderate poverty (defined in terms of the R250 poverty line) did, both in terms of the extent and depth of poverty.

At the same time as poverty rose, real household income in the uppermost quantiles increased, causing a rise in income inequality. The authors note that this is the first time that inequality for the total population has increased beyond the level it stabilised at in 1975: the Gini coefficient increased from 0.68 in 1996 to 0.73 in 2001 (Leibbrandt et al. 2006: 100). The driver of the observed increase was increasing variation in incomes within race groups, rather than variation across race groups. The authors also highlight the fact that two trends that had been observed in the income distribution since the 1970s had come to an end by 1996. There was no change in blacks' share of total income (i.e. 38\%) between 1996 and 2001, ending the long-term increase in this racial share that had been noted before. Further, the gap between white and black mean per capita incomes widened over the period, reversing the prior trend (Leibbrandt et al. 2006: 102-103).

Having reviewed the studies that suggest poverty has increased, the focus of this review now turns to empirical work that suggests that poverty may have stabilised or declined since political transition. The UNDP's 2003 Human Development Report for South Africa (UNDP 2003) as well as research by Simkins (2004) and Van der Berg and Louw (2004) fall into this category.

The UNDP worked with three poverty lines: the international $\$ 1$ and $\$ 2$ a day lines, as well as a national poverty line set at R354 in 1995 Rand to cover the UNDP's estimated cost of satisfying minimum dietary requirements. Contrasting data for $2002^{3}$ with the IES 1995 and using the national poverty line, the UNDP found that the proportion of people living in poverty had fallen from $51.1 \%$ to $48.5 \%$ over the period (UNDP 2003: 41). Despite this decline, the absolute number of people living in poverty by this measure had increased from 20.2 million to 21.9 million as a result of population growth. The poverty headcount ratio ${ }^{4}$ using the $\$ 2$ a day poverty

\footnotetext{
${ }^{3}$ Chapter 2 of the Human Development Report - in which the findings on poverty are presented - does not mention which dataset for 2002 is employed for purposes of analysis. We presume that one of the two LFS datasets collected in 2002 is used.

${ }^{4}$ The poverty headcount ratio measures the proportion of individuals in the total population living below a given poverty
} 
line also decreased slightly (from $24.2 \%$ to $23.8 \%$ ), although disturbingly the headcount ratio for the most extreme poverty - measured on the basis of the $\$ 1$ a day line - increased from 9.4\% to 10.5\% (UNDP 2003: 41). The UNDP reported that while the extent of poverty appeared to have declined slightly, the depth of poverty (measured by the poverty gap) increased, particularly when using lower poverty lines. Commenting on the income distribution as a whole, the UNDP (2003: 43) suggested that inequality was worsening: the estimated Gini coefficient rose from 0.596 in 1995 to 0.635 in 2002.

Simkins (2004) performed analysis on the 1995 and 2000 IESs as well as the 1996 and 2001 Censuses in an attempt to arrive at robust conclusions regarding the paths of poverty and inequality in the post-transition period. He used a per capita poverty line consistent with a household income of R800 per month. Before applying the standard distributional analysis techniques, the author adjusted the data where it appeared incorrect or incomplete. His research indicates that inequality increased substantially between 1995 and 2001, although it provided less evidence of a trend in poverty. On the basis of known errors in the datasets, Simkins (2004: 10) suggests that poverty may have worsened somewhat over the period.

Van der Berg and Louw (2004) analysed the post-apartheid income distribution using the IES datasets for 1995 and 2000. At the start of their analysis they noted that current household income as captured in the national accounts rose over the period, which is inconsistent with the decline in household incomes that is obtained when the two IES datasets are contrasted. Accordingly, the authors calculated mean incomes for each race group using national accounts and other sources of data, and then applied these to the intra-group distributions of income contained in the IES datasets ${ }^{5}$. Setting the poverty line at R250 per month in 2000 Rand (broadly consistent with Woolard and Leibbrandt 2001), Van der Berg and Louw (2004: 567) found that the poverty headcount ratio stabilised or even declined slightly over 1995-2000, although the number of people living in poverty increased due to population growth. Their work shows evidence of a fairly small increase in inequality within race groups (Van der Berg \& Louw 2004: 566).

\section{WHY CAN WE NOT TRUST OFFICIAL SOURCES OF DISTRIBUTION DATA?}

The literature review has alluded to deficiencies in official datasets covering the post-transition period that have serious consequences for the reliability of comparative exercises. The Population Censuses provide researchers with rich datasets that do not suffer from any potential sampling problems. However, they collect income data in a relatively small number of bands, implying that analysts are required to derive income in one of a number of ways before performing distributional analysis; this can affect the reliability of derived poverty and inequality trends. Ardington et al. (2005) show that inequality levels are generally underestimated as a result of collecting income information in bands (as opposed to point estimates), although fortunately not by much.

A more serious problem is that Census data for 1996 and 2001 suffer doubly from a high number of households reporting zero incomes and a large number of missing observations for personal income. "Zero-income"

line. The poverty headcount is simply the number of individuals living in poverty.

${ }^{5}$ This technique is also utilised in the current study, and is explained in more detail in the Appendix. 
households amount to $12.6 \%$ of the total in 1996, and 23.2\% of households in 2001 (Simkins 2004: 6). In 1996, $11.8 \%$ of households returned missing values for one or more members (Simkins 2004: 6), while in 2001 incomes were imputed for the large number of households that did not provide income data. In this year more than a quarter of all individuals were found in households where some of the individuals did not report their income (Ardington et al. 2005: 7). Imputing incomes for households with missing or reported zero incomes, Ardington et al. (2005) found that estimates of mean income and inequality are higher than when these households are excluded, while estimates of poverty are lower. The reason for this is that survey non-response was higher for households in urban areas and amongst whites - groups that are more affluent on average.

The IES surveys have some features that make them particularly suitable for asking questions about trends in poverty. They are large enough to be representative, and they obtain point estimates of income and expenditure. However, issues that make comparability particularly difficult plague the 1995 and 2000 datasets. Two years after publishing its report contrasting the results of these surveys, Statistics South Africa admitted that the two surveys were not directly comparable. Benchmarked against population figures from Census 2001, the IES2000 underrepresents the white population while over-representing the black population (Hoogeveen \& Özler 2004: 41). This is reflected in property income estimates from IES2000, which are too low to be reliable (Simkins 2004: 4). In fact, there is a large gap between the estimates of total household income from the IES2000 and national accounts data (Vermaak 2005: 2). Attempting to correct for this problem is not an easy task. Hoogeveen and Özler (2004) re-weight the racial populations from the IES2000 in line with the estimates of racial shares from Census 2001. However, Vermaak (2005: 6) points out that this assumes that incorrect sampling occurs randomly across each racial population, rather than being a systematic problem for households of a certain expenditure range. If the assumption is false, then "correcting" for poor sampling does not accomplish its purpose. The observed discrepancies may be due to changes in the sampling design and varying quality of fieldwork and data management. In addition to the incorrect sampling of population groups in IES2000, data management also seems to be worse in this survey than in the 1995 round: the number of zero responses for food expenditure reporting is substantially higher, and there are more cases of large gaps between household income and expenditure (which are designed to be equal).

\section{THE ALL MEDIA AND PRODUCT SURVEY (AMPS)}

The AMPS has been conducted semi-annually or annually by the South African Advertising Research Foundation (SAARF) since 1975. The main purpose for which it is used is market research; a substantial amount of South African advertising expenditure is allocated according to information drawn from the survey. From year to year the number of households surveyed differs, historically ranging from 14000 in the early 1990s to well over 20 000 from 1997 onwards. One respondent aged 16 or above from each household is asked to fill in the questionnaire (this person is not necessarily the household head). As the name of the survey suggests, data on the usage of a wide range of household goods and services are collected. However, this study is primarily concerned with the information on household income, which is collected through showing respondents cue cards divided into 28 or more categories (surveys in more recent years include up to 32 income categories). Where a 
respondent withholds such information, SAARF imputes household income on the basis of household expenditure implied by the product questionnaire.

In light of the fact that the AMPS survey has not been used for formal distributional analysis before, this paper first describes the survey sampling frame and methodology. Regarding sampling design and methodology, the sample is stratified first by province and then by the size of a community. Communities are grouped into metropolitan areas (250 000 or more inhabitants), cities (100 000 - 249999 inhabitants), large towns (40 000 100000 inhabitants), small towns (8 $000-40000$ inhabitants), rural areas and farming communities. Large and small towns are grouped together, and rural areas and farming communities are grouped together. All metropolitan areas and cities are sampled. For the remaining community types, category communities are ranked according to size, and then randomly selected. Within the selected communities, interview points are randomly selected. Two addresses are selected at each interview point. (If there is more than one household at any address, the households are surveyed separately.) Within households, a respondent is chosen according to the Politz methodology - for example, within each cluster of two households, one man and one woman are interviewed, each from separate households. Interviewers must return to a selected address a further three times if the first attempt to survey the people living there proved unsuccessful. Only then will substitution be allowed.

Cell weighting is allocated by province (of which there are nine), community type (of which there are four), age group (of which there are four) and gender. The gender and age weights come from the Bureau of Market Research, which provides estimates of the country's demographic composition. This yields a total of 288 cells each containing a minimum of 10 people. The ratio of weights across any pair of cells amongst the total of 288 may not exceed 2:1.

After weights are applied, the data are externally validated using the following data sources:

- $\quad$ Subscriber data from MNet;

- New electricity connections from ESKOM (that is, those made during the past 12 months).

Validation occurs by checking whether the AMPS figures fall within the $95 \%$ confidence intervals generated by these data sources. There is also internal validation using historical sales data for consumer durables with long lifespans and low duplication rates (such as microwaves and computers); in the AMPS product questionnaire, consumers indicate whether they have made purchases of these goods during the past 12 months.

The preceding discussion reflects that SAARF has gone to considerable effort to ensure that the AMPS is a reliable data source. Indeed, further analysis in this paper provides evidence of a great deal of stability in the data between 1993 and 2004. It should be acknowledged that the survey might undercapture variability amongst households in rural areas relative to those in urban areas - a likely consequence of its focus on household consumption patterns. Approximately $15 \%$ of households surveyed for AMPS come from areas defined as rural by SAARF. By contrast, the IES samples households in location proportions closer to those reflected by the Census: $45 \%$ of the total came from rural areas in $1995,39 \%$ in 2000 . The first important caveat to bear in mind is that location types are not defined in the same way in AMPS as they are by Stats SA, so while it may be 
tempting to make them, strict comparisons should be avoided. The second is that the numbers of households surveyed in rural areas for AMPS are still fairly large, despite these households not constituting the focus of the study. More than 2000 rural households were included even in years in which smaller surveys were conducted. Thirdly, once weights are applied, the AMPS and IES distributions of the population across urban and rural areas are much more similar (for 2000: IES population is 59\% urban and 41\% rural; AMPS population is $56 \%$ urban, $44 \%$ rural).

\section{ANALYSIS OF THE SOUTH AFRICAN INCOME DISTRIBUTION: 1993-2004}

The starting point for distributional analysis is an exercise aimed at determining the reliability of AMPS data. For this purpose, aggregate household income from the AMPS is expressed below as a ratio of current household income from the national accounts. Whatever misgivings one has about the accuracy of national accounts data, these series provide arguably the most consistent series of household income over time in South Africa, and are accordingly selected as the appropriate benchmark.

Table 1: Comparison of AMPS and national accounts estimates of aggregate household income

\begin{tabular}{|l|r|r|r|r|r|r|}
\hline & \multicolumn{1}{|c|}{$\mathbf{1 9 9 3}$} & \multicolumn{1}{|c|}{$\mathbf{1 9 9 5}$} & \multicolumn{1}{|c|}{$\mathbf{1 9 9 7}$} & \multicolumn{1}{c|}{$\mathbf{2 0 0 0}$} & \multicolumn{1}{c|}{$\mathbf{2 0 0 2}$} & \multicolumn{1}{c|}{$\mathbf{2 0 0 4}$} \\
\hline AMPS aggregate household income (R mill) & 336394 & 333057 & 347982 & 404952 & 416048 & 450696 \\
National accounts current household income (R mill) & 513020 & 555525 & 606201 & 677773 & 715192 & 796597 \\
Ratio of AMPS to national accounts totals & $66 \%$ & $60 \%$ & $57 \%$ & $60 \%$ & $58 \%$ & $57 \%$ \\
\hline
\end{tabular}

Sources: South African Reserve Bank; All Media and Products Survey

As can be seen, the ratio hovers around 60\% for the entire period, with downward deviations between 1997 and 1999 probably being caused by under-estimates of the population for these years ${ }^{6}$. The deviation upwards in 1993 is suspect, and suggests that the AMPS survey for this year may be less reliable than the rest; the implications of this irregularity are discussed in a later section. On the whole, however, the AMPS' capturing of aggregate household income as reflected in the national accounts is relatively consistent over time. It is also more stable than income capturing in the post-transition IESs and Censuses, and undercapturing of income is a less serious problem than in either of these Statistics South Africa data sources. Furthermore, it seems to reflect approximately the same concept of household income that the national accounts data reflect. Over the period 1993 to 2004, AMPS aggregate household income grew by 64\% in total, compared with very similar growth in current household income in the national accounts of $67 \%$. It is encouraging to observe that AMPS' undercapturing of income thus does not appear to be worsening over time, which has been the case with official surveys in India, amongst others (Karshenas 2003). Similarly, household size is roughly stable over time, showing a gradual decrease that is consistent with slowly improving labour market conditions and the post-1994 rollout of the RDP housing delivery programme.

${ }^{6}$ SAARF chose not to rely on Stats SA's estimates of the population from the 1996 Census, and thus did not allow for population growth based on these figures over the period 1997-1999. 


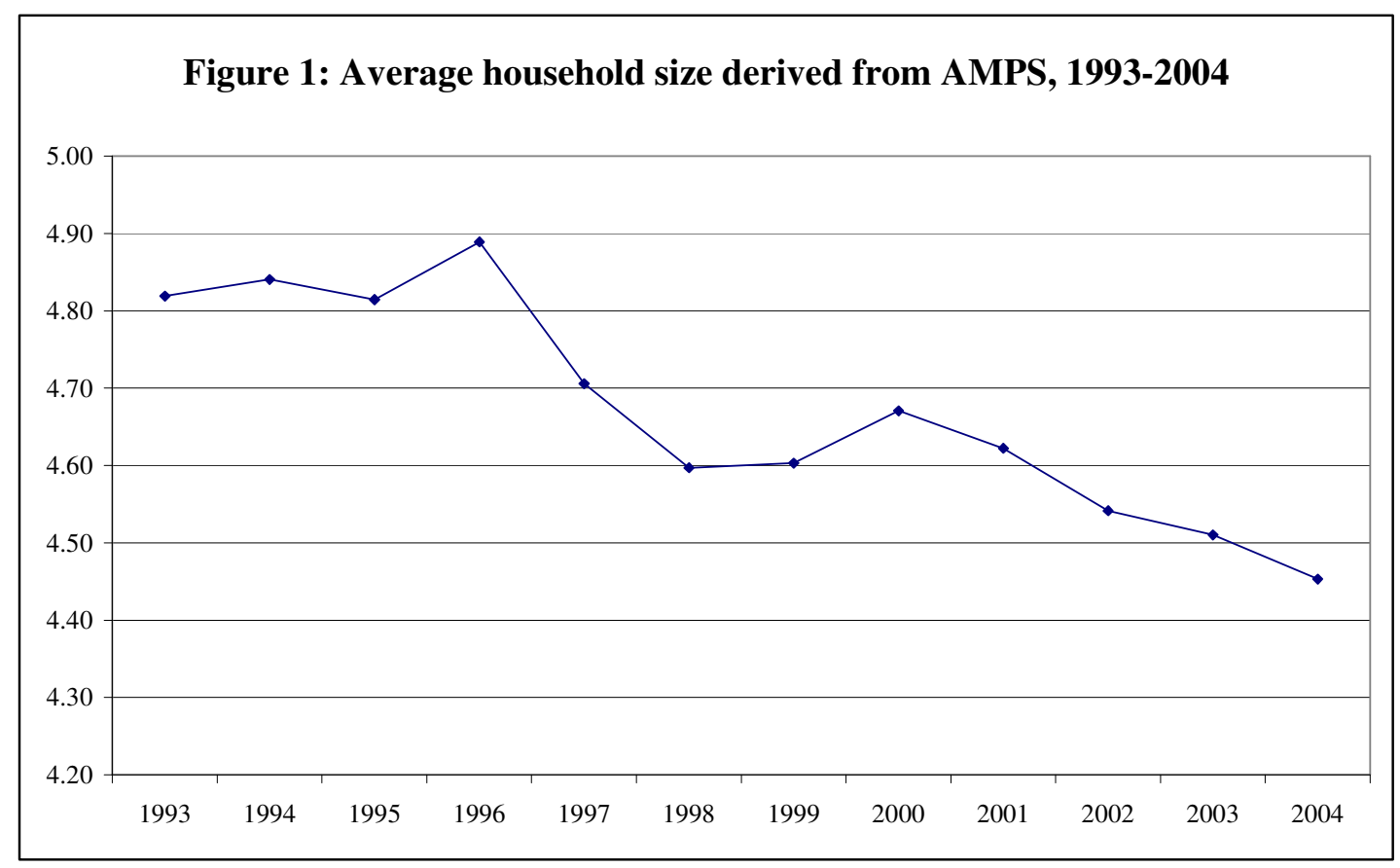

Having established that aggregate AMPS estimates of income are roughly compatible with official estimates of household income in South Africa, analysis proceeds to measuring trends in per capita income, poverty and inequality.

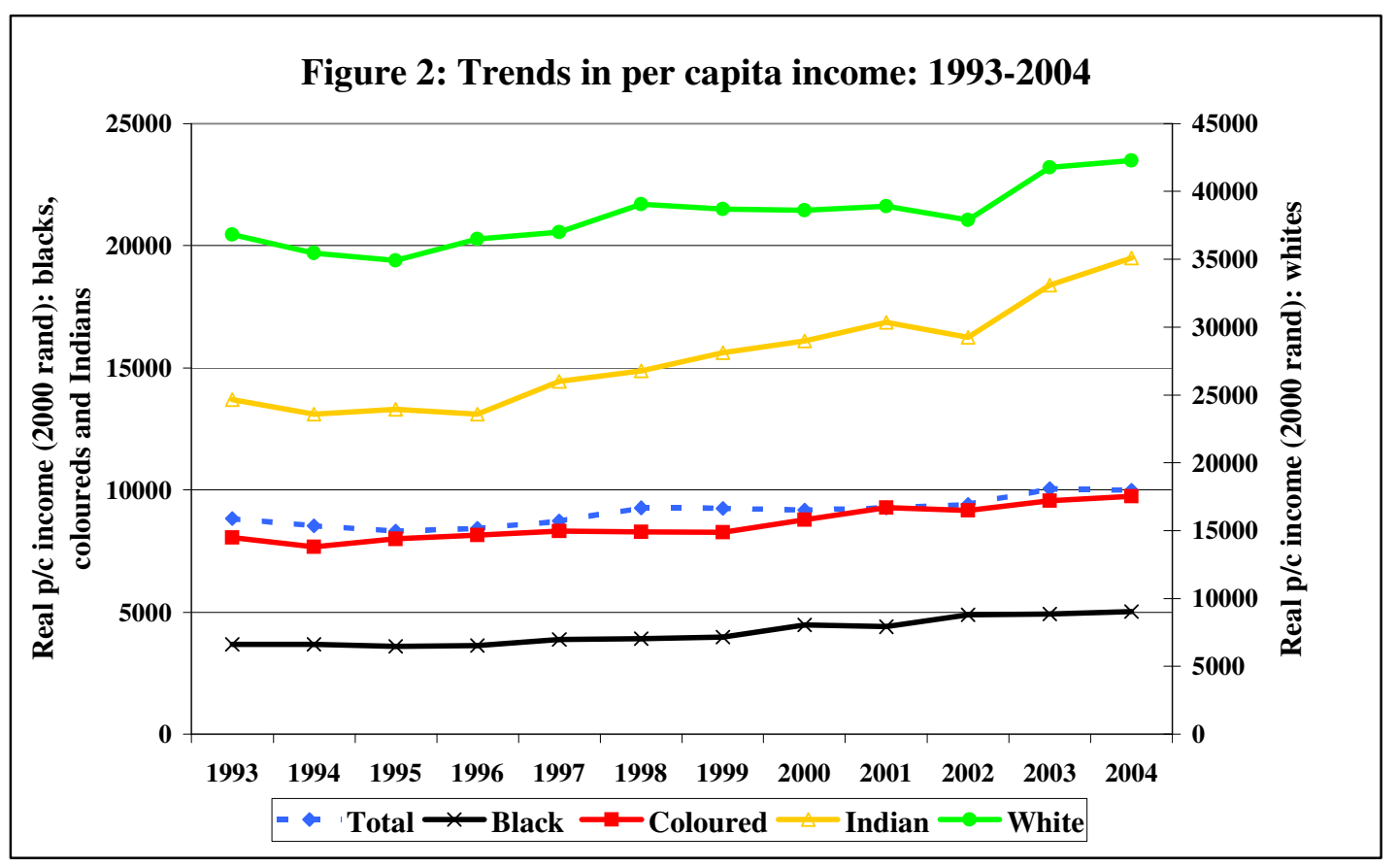

It is clear that real incomes for all race groups have increased since the mid 1990s, with especially substantial increases from 2002 onwards. The robust growth in white incomes during the mid 1990s and again from 2002 onwards can be attributed to members of the white group maintaining a constant share of wage income, increasing their share of property income and experiencing negative population growth. Indian incomes also 
appear to have been climbing steadily throughout the post-transition period, for similar reasons to those applying to white incomes. The modestly accelerating economic growth rates experienced during the first post-transition decade and an improvement in the ability of the economy to generate jobs are likely to have benefited these groups in particular, given their relatively large stocks of human capital. While blacks and coloureds have also benefited from these developments, as members of the poorest two population groups they have also been the primary beneficiaries of the rapid expansion in South Africa's social safety net system.

Between 2000/01 and 2004/05, social grant payments doubled, rising by more than R18 billion in real terms (2000 Rand) $)^{7}$. The bulk of the additional grant spending came in the form of assistance for households containing children, with the age limit for eligibility for the child support grant (CSG) being raised to 14 . In addition, there were substantial increases in the number of beneficiaries of the disability grant, foster care grant and the care dependency grant. The table below, showing the number of beneficiaries of each social grant in 2000 and 2004, reflects these trends.

Table 2: Social grants, 2001/02-2004/05

\begin{tabular}{|l|r|r|r|r|r|}
\hline \multirow{2}{*}{ Type of grant } & Grant value & \multicolumn{4}{|c|}{ Beneficiary numbers } \\
\cline { 2 - 6 } & April 2004 & \multicolumn{1}{|c|}{$2001 / 02$} & $2002 / 03$ & $2003 / 04$ & \multicolumn{1}{c|}{$2004 / 05$} \\
\hline Old age pension & R 740 & 1877538 & 1903042 & 2009419 & 2060421 \\
\hline War veteran & R 740 & 6175 & 5266 & 4594 & 3961 \\
\hline Disability & R 740 & 627481 & 694232 & 953965 & 1270964 \\
\hline Grant-in-aid & R 170 & 9489 & 10332 & 12787 & 18170 \\
\hline Foster care & R 540 & 85910 & 95216 & 138763 & 200340 \\
\hline Care dependency & R 780 & 28897 & 34978 & 58140 & 77934 \\
\hline Child support & R 170 & 974724 & 1907774 & 2630826 & 4309772 \\
\hline
\end{tabular}

Source: National Treasury (2005: 55)

Attention turns next to the results of analysis of AMPS data. Steadily increasing black per capita incomes coupled with positive population growth rates (as opposed to negative white population growth) are reflected in changes in the racial shares of total income in favour of this group. This is the continuation of a longer-term trend that began in the 1970s. Trends in the racial shares of wage income, drawn from OHS and LFS data, mirror the post-

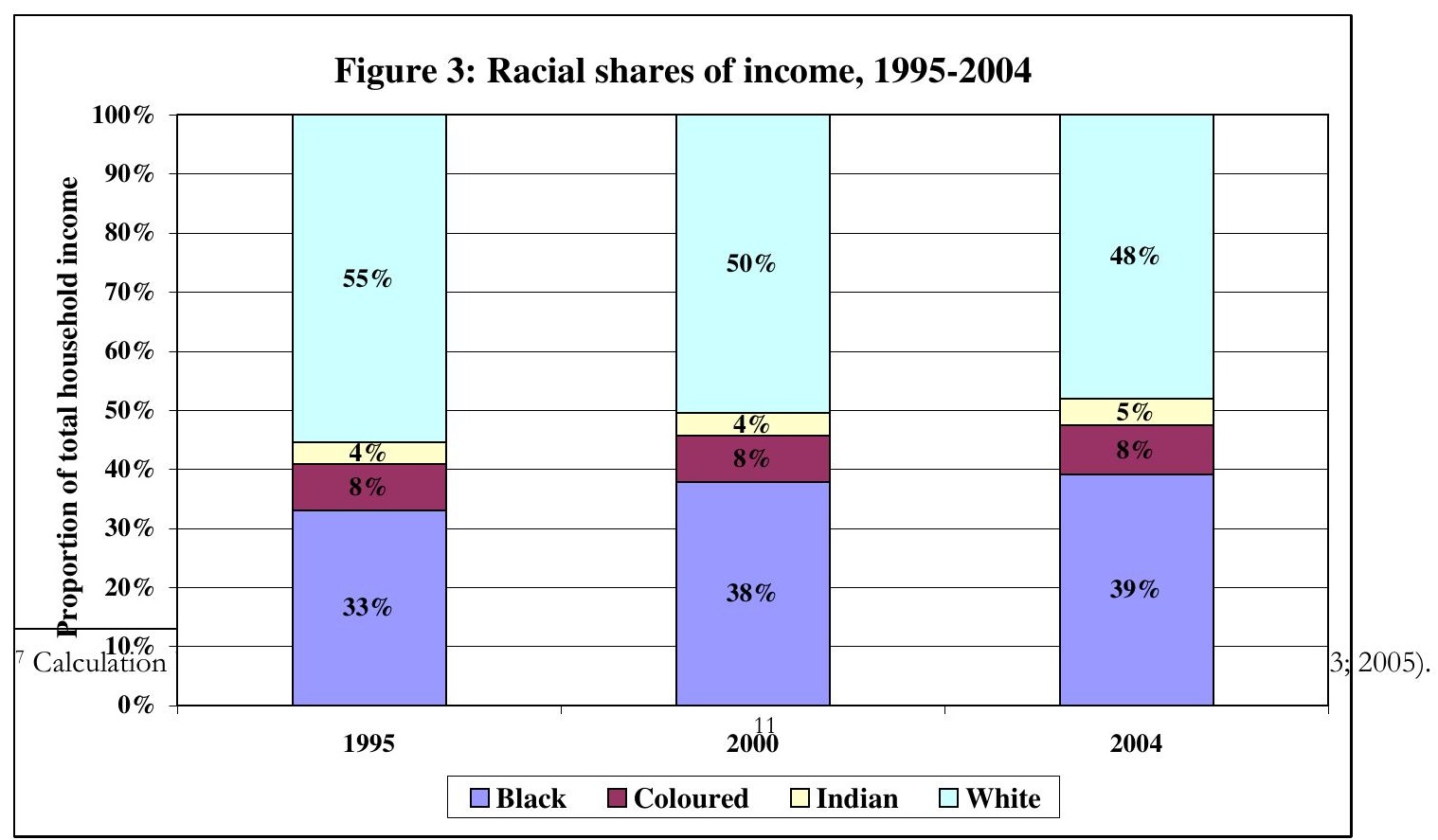


transition movements in racial shares of total income observed from the AMPS.

Encouraging upward trends in per capita incomes are only one part of a broader story, the telling of which requires closer examination of the income distribution. To describe the degree of income dispersion, three measures are used: the conventional Gini index, Theil-T index, and the mean log deviation. Both the Theil-T index and the mean log deviation belong to the class of general entropy inequality measures, which are functions of parameter $\theta$. The larger $\theta$ is, the more sensitive the index is to income differences at the bottom of the distribution. Setting $\theta$ equal to 0 yields the mean logarithmic deviation, which is the average of $\log$ mean income/expenditure divided by each individual's income/expenditure. This measure of inequality is particularly sensitive to changes at the bottom of the income distribution, and is therefore most useful if one judges deterioration in material welfare to be particularly deleterious when it involves a drop in the incomes of the poor. By contrast, the Gini index is most sensitive to changes in the middle of the income distribution (Hoogeveen \& Özler 2004: 12). Setting $\theta$ equal to one yields the Theil indices, of which the Theil-T - which weights sub-groups by income share - is the most frequently used. An advantage of the Theil indices is that they allow for decomposition of aggregate inequality into between-group and within-group components, enabling one to derive trends in racial inequality. 
Table 3: Income inequality measures, 1993-2004

\begin{tabular}{|c|c|c|c|c|}
\hline \multicolumn{5}{|c|}{ Gini coefficient } \\
\hline & 1993 & 1995 & 2000 & 2004 \\
\hline Blacks & 0.547 & 0.568 & 0.609 & 0.598 \\
\hline Coloureds & 0.529 & 0.507 & 0.537 & 0.550 \\
\hline Indians & 0.465 & 0.473 & 0.500 & 0.542 \\
\hline Whites & 0.443 & 0.438 & 0.467 & 0.500 \\
\hline Total & 0.672 & 0.674 & 0.682 & 0.678 \\
\hline \multicolumn{5}{|c|}{ Theil-T index } \\
\hline & 1993 & 1995 & 2000 & 2004 \\
\hline Blacks & 0.506 & 0.554 & 0.685 & 0.660 \\
\hline Coloureds & 0.425 & 0.380 & 0.446 & 0.483 \\
\hline Indians & 0.289 & 0.339 & 0.399 & 0.534 \\
\hline Whites & 0.258 & 0.256 & 0.306 & 0.399 \\
\hline Total & 0.899 & 0.899 & 0.935 & 0.967 \\
\hline Within-race & 0.350 & 0.366 & 0.464 & 0.514 \\
\hline Between-race & 0.549 & 0.533 & 0.471 & 0.453 \\
\hline $\begin{array}{l}\text { Contribution of within- } \\
\text { race component to } \\
\text { total }\end{array}$ & $39 \%$ & $41 \%$ & $50 \%$ & $53 \%$ \\
\hline \multicolumn{5}{|c|}{ Theil-L index / Mean logarithmic deviation } \\
\hline & 1993 & 1995 & 2000 & 2004 \\
\hline Blacks & 0.478 & 0.535 & 0.615 & 0.586 \\
\hline Coloureds & 0.443 & 0.392 & 0.460 & 0.496 \\
\hline Indians & 0.306 & 0.315 & 0.376 & 0.468 \\
\hline Whites & 0.274 & 0.264 & 0.316 & 0.377 \\
\hline Total & 0.905 & 0.927 & 0.938 & 0.910 \\
\hline Within-Race & 0.444 & 0.484 & 0.562 & 0.552 \\
\hline Between-Race & 0.461 & 0.442 & 0.376 & 0.358 \\
\hline $\begin{array}{l}\text { Contribution of within- } \\
\text { race component to } \\
\text { total }\end{array}$ & $49 \%$ & $52 \%$ & $60 \%$ & $61 \%$ \\
\hline
\end{tabular}

The picture created above is one of rising aggregate inequality during the 1990 s, followed by stabilisation - and possibly even a small decline - from the turn of the century onwards. However, even after 2000 intra-racial inequality continued to rise for all groups, with the notable exception of blacks. This escalation is particularly rapid if one draws inference from the mean logarithmic deviation rather than the conventional Gini. The small but surprising decline in black inequality is consistent with a scenario in which the expansion of social grants and - to a lesser extent - recent improvements in job prospects have benefited poor individuals more than proportionately. Decomposition of the Theil index shows that income inequality between race groups declined throughout the period, offsetting the rising inequality within groups. This trend of falling inter-racial inequality coupled with rising intra-racial inequality is also a continuation of a longer-term phenomenon, observed first in the 1970s (Whiteford \& Van Seventer 2000). Note that these estimates of the population Gini are near the upper end of South African Gini estimates, although they remain smaller than those calculated by Ardington et al. (2005) using the 2001 Census. It is argued here that trends in inequality derived from the AMPS Gini coefficients are likely to be more reliable than the estimated levels of inequality that they reflect.

Attention focuses next on trends at the lower end of the income distribution. Post-transition poverty trends are 
of great interest and concern in policy debate, as their aggregate direction establishes whether the government has succeeded in a critical socio-economic objective. This paper therefore aims to establish with as much confidence as possible whether or not poverty has declined since 1994. The poverty line is set at R250 per month in 2000 Rand values, in line with the earlier research by Van der Berg and Louw (2004). This is higher than the $\$ 2$ a day line, which converts into R174 per month in 2000 Rand. It therefore encompasses both severe and more moderate poverty, although it remains lower than the cost-of-basic-needs measure employed by Hoogeveen and Özler (2006). For purposes of analysis in this paper, the Foster-Greer-Thorbecke poverty measures are employed. The poverty headcount $\left(\mathrm{P}_{0}\right)$ reflects the extent of poverty; the poverty gap index $\left(\mathrm{P}_{1}\right)$ reflects the depth of poverty; and the squared poverty gap index $\left(\mathrm{P}_{2}\right)$ reflects the severity of poverty. In the case of $\mathrm{P}_{0}$, two figures are presented: the headcount rate (percentage of the population falling below the poverty line) and the headcount itself (the number of people falling below the poverty line).

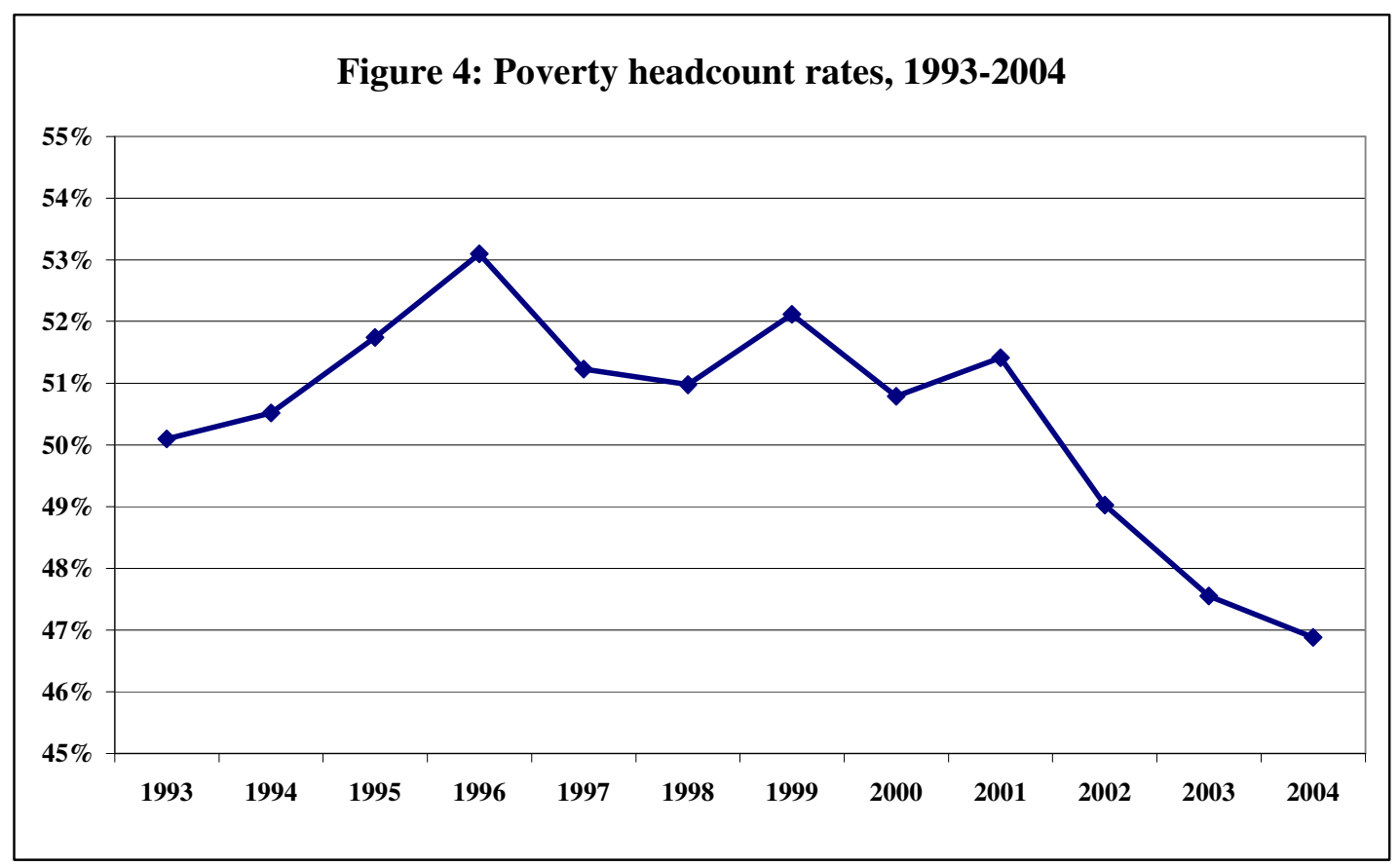


Table 4: Poverty trends, 1993-2004

\begin{tabular}{|c|c|c|c|c|c|}
\hline Group & FGT & 1993 & 1995 & 2000 & 2004 \\
\hline \multirow{4}{*}{ All } & $\mathrm{P}_{0}$ headcount rate & $50.1 \%$ & $51.7 \%$ & $50.8 \%$ & $46.9 \%$ \\
\hline & $\mathrm{P}_{0}$ headcount & 20002068 & 21397486 & 22704130 & 21785700 \\
\hline & $\mathrm{P}_{1}$ & 0.2419 & 0.2678 & 0.2539 & 0.2193 \\
\hline & $\mathrm{P}_{2}$ & 0.1482 & 0.1711 & 0.1547 & 0.1276 \\
\hline \multirow{4}{*}{ Blacks } & $\mathrm{P}_{0}$ headcount rate & $63.0 \%$ & $64.7 \%$ & $62.3 \%$ & $57.0 \%$ \\
\hline & $\mathrm{P}_{0}$ headcount & 19171230 & 20491823 & 21560365 & 20731068 \\
\hline & $\mathrm{P}_{1}$ & 0.3076 & 0.3398 & 0.3155 & 0.2699 \\
\hline & $\mathrm{P}_{2}$ & 0.1894 & 0.2188 & 0.1934 & 0.1578 \\
\hline \multirow{4}{*}{ Coloureds } & $\mathrm{P}_{0}$ headcount rate & $27.6 \%$ & $26.2 \%$ & $26.9 \%$ & $26.0 \%$ \\
\hline & $\mathrm{P}_{0}$ headcount & 934031 & 915136 & 1009649 & 1022562 \\
\hline & $\mathrm{P}_{1}$ & 0.1068 & 0.0956 & 0.0998 & 0.0974 \\
\hline & $\mathrm{P}_{2}$ & 0.0572 & 0.0463 & 0.0511 & 0.0501 \\
\hline \multirow{4}{*}{ Indians } & $\mathrm{P}_{0}$ headcount rate & $6.4 \%$ & $5.7 \%$ & $5.7 \%$ & $6.4 \%$ \\
\hline & $\mathrm{P}_{0}$ headcount & 65484 & 59416 & 62578 & 73097 \\
\hline & $\mathrm{P}_{1}$ & 0.0178 & 0.0167 & 0.0208 & 0.0215 \\
\hline & $\mathrm{P}_{2}$ & 0.0079 & 0.0069 & 0.0106 & 0.0108 \\
\hline \multirow{4}{*}{ Whites } & $\mathrm{P}_{0}$ headcount rate & $0.5 \%$ & $0.5 \%$ & $0.8 \%$ & $1.0 \%$ \\
\hline & $\mathrm{P}_{0}$ headcount & 26825 & 25659 & 43640 & 49203 \\
\hline & $\mathrm{P}_{1}$ & 0.0026 & 0.0015 & 0.0027 & 0.0039 \\
\hline & $\overline{\mathrm{P}_{2}}$ & 0.0017 & 0.0008 & 0.0013 & 0.0024 \\
\hline
\end{tabular}

The story told by these numbers is one of increasing poverty around the mid 1990s, followed by a period of stability until the turn of the century, and then by a dramatic reduction in poverty after 2001 . The initial increase in poverty is probably due to a combination of sluggish economic growth and poor labour market prospects in the second half of the 1990s. However, note that the progress made in fighting poverty since 2001 has been large enough to more than offset the preceding rise in poverty. It is clear that the drop in poverty is driven by upward income mobility amongst blacks; there is little evidence of a trend in the extent of coloured and Indian poverty over the period (although Indian poverty does appear to be growing more deep and severe over time, but from a very low base), while white poverty even increased slightly. The recent substantial decline in the extent of poverty is likely to be the result of a combination of factors including faster economic growth, improving labour market prospects and swelling social grant spending. Such factors are also likely to be underlying the decline in the depth and severity of poverty over the period. Trends in $\mathrm{P}_{1}$ and $\mathrm{P}_{2}$ mirror those observed in $\mathrm{P}_{0}$, improvement once again driven by rising welfare amongst the black population.

The speed of the decline in poverty from 2002 onwards is striking, and may be challenged as being the result of quirks in the AMPS data. To investigate this, the issue is investigated further:

- The impact of the recent expansion of social grants on the poor is likely to have been major, considering that real transfers from government increased by some R22 billion in the last two years (in 2000 Rand value), an amount well in excess of R1 000 per poor person. Bear in mind that poverty is defined as income of less 
than R3000 per capita per year in this paper. The grants are supposed to be targeted through the means test, thus most of the additional R18 billion flows into poor households. Considering that the income of the poor was only R27 billion in 2000, an increase in social grants of this size would make a great difference to the poor and may lift many of them out of poverty if grants are well targeted. Indeed, research on KIDS data for black and Indian households in KwaZulu-Natal shows that the amount of transfers per household doubled between 1998 and 2004 (Agüero et al. 2005).

- From national accounts data, real remuneration rose by R53 billion in real terms between 2002 and 2004 , representing an exceptionally large increase in terms of South African experience of $11.7 \%$ over the period. This effect, if accurately measured, must have had a strongly positive influence on the incomes of many of the poor, either through higher wages or through increased employment.

- Income distribution, particularly in the black population, is relatively clustered around the poverty line. This means that small shifts in the distribution could have large impacts on poverty. The implications for poverty of distributional shifts are particularly large if black incomes change, given the size of this group and the observed clustering of black incomes near the poverty line. Thus, the impact of grants on poverty is strongest if grants contribute predominantly to black incomes (as one would think they do).

In summary, analysis on AMPS data shows that there has been a marked decline in poverty since the turn of the century. These results are broadly consistent with the UNDP's (2003) finding that the extent of poverty declined slightly over the period 1995-2002. The direction of the trend in poverty over 1993-2000 is consistent with the findings of other authors who have found that poverty increased during the second half of the 1990s (Hoogeveen \& Özler 2004; Leibbrandt et al. 2005; Leibbrandt et al. 2006; Meth \& Dias 2004), although the magnitude of the increase implied by the AMPS is not consistent with the massive income decline obtained from the IES, as described by Leibbrandt et al. (2005).

Since the level at which a poverty line is set may make a large difference to conclusions regarding trends in poverty, one may question the robustness of any poverty analysis based on a single poverty line. For this reason, cumulative density functions are plotted to determine whether stochastic poverty dominance holds. Observe that the distribution in 2004 strictly dominates the distribution in 1995, i.e. poverty is lower (in terms of extent, depth and severity) over any reasonable range of poverty lines. However, the conclusions with respect to 1993 are not as strong; the distribution in 2004 weakly dominates the one in 1993, implying that poverty is equivalent or lower over a range of plausible poverty lines in 2004 than in the earlier year. This more ambiguous conclusion may be the result of either of two phenomena: a decade of fighting poverty reaping gains only large enough to return South Africa to its position pre-1994, or quirks in the 1993 data. Evidence of the second is provided in the implausibly big jump in the value of the mean logarithmic deviation for blacks between 1993 and 1995 (refer back to Table 3). 
Figure 5: Cumulative density functions, AMPS

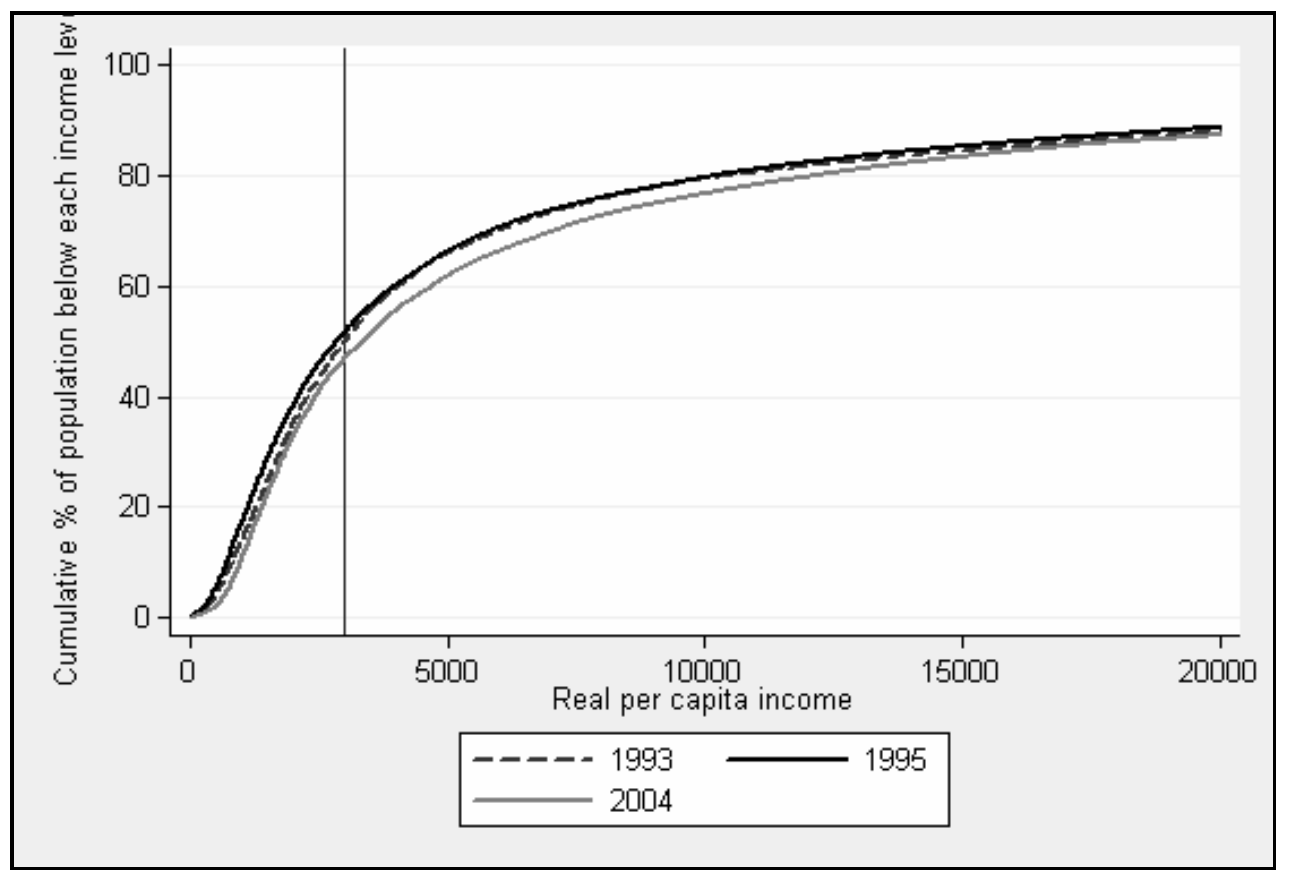

The rapidly growing black middle class is a natural consequence of advancement in the living conditions of black people at the lower end of the income distribution. To be broadly inclusive, the middle and upper classes are defined here as comprising individuals with an annual per capita household income of at least R15 000 (2000 Rand value). Two things are immediately evident: the ranks of the middle and upper classes are swelling, and this rise is driven by burgeoning black purchasing power. Between 1993 and 2004, the size of the group defined here as relatively affluent grew by approximately 1.5 million; over the same period, the number of blacks belonging to this group escalated by 1.3 million. Consequently, blacks constituted almost $40 \%$ of the middle and upper classes by 2004, more than doubling in relative importance from a low base of 15\% of the total in 1993 . Further, their share of the total income accruing to this group mushroomed, from $10 \%$ in 1993 to $22 \%$ in 2004 . 


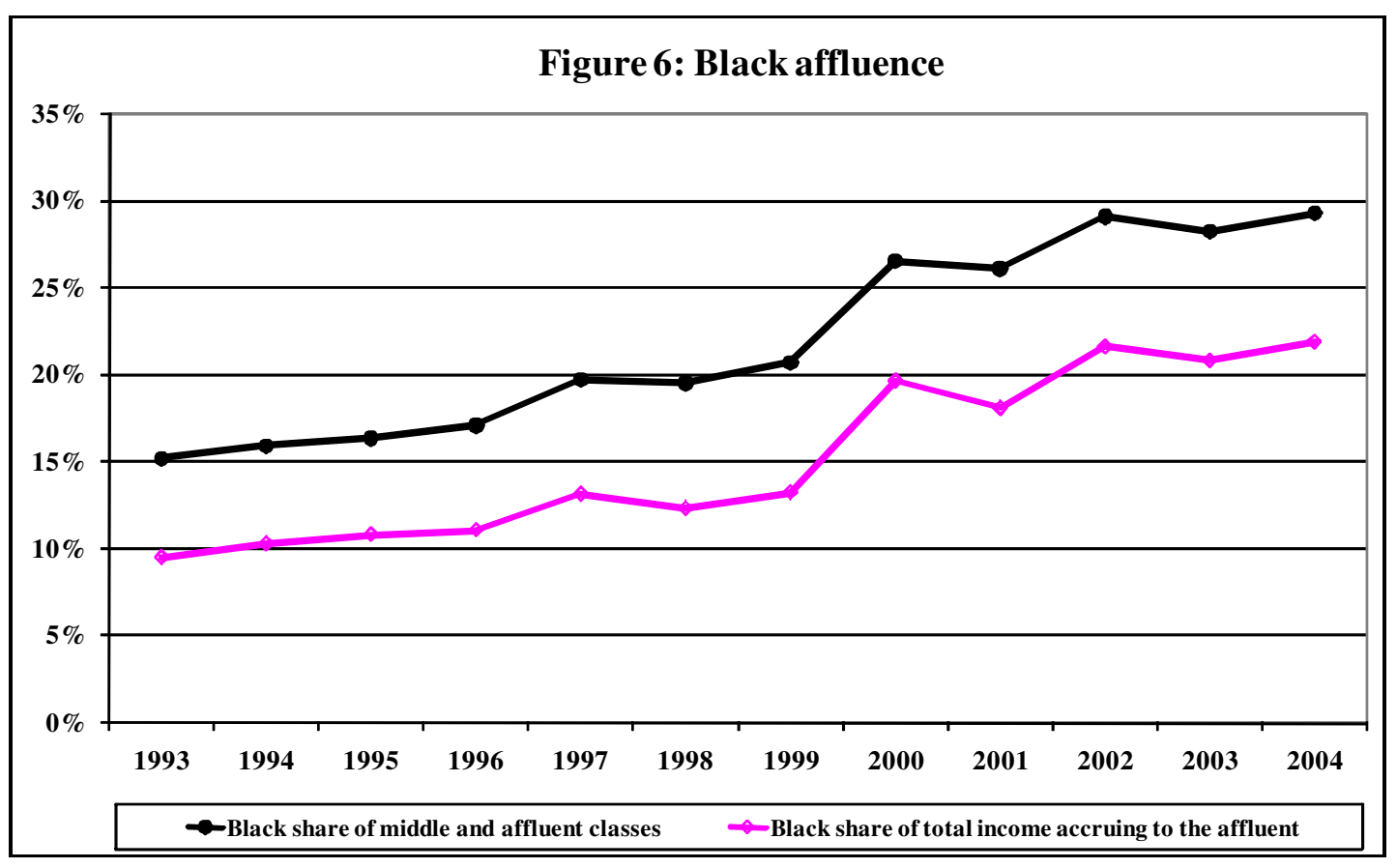

\section{MORE REASON TO BELIEVE THAT POVERTY HAS DECLINED}

\section{Table 5: The middle and affluent classes, 1993-2004}

\begin{tabular}{|l|r|r|}
\hline & $\mathbf{1 9 9 3}$ & $\mathbf{2 0 0 4}$ \\
\hline Total size of middle and affluent classes & 6136730 & 7671767 \\
\hline Number of blacks in middle and affluent classes & 935026 & 2249103 \\
\hline Middle class and affluent people as proportion of population & $15 \%$ & $17 \%$ \\
\hline Middle class and affluent blacks as proportion of population & $2 \%$ & $5 \%$ \\
\hline Proportion of people in middle and affluent classes who are black & $15 \%$ & $29 \%$ \\
\hline Black share of total income accruing to middle and affluent classes & $10 \%$ & $22 \%$ \\
\hline
\end{tabular}

The central contribution of this paper to the current income distribution literature is its empirical finding of a reduction in poverty in recent years. However, doubts about the reliability of the AMPS poverty trends may remain, associated with peculiarities in the AMPS sampling frame, design or methodology. For this reason, three additional pieces of evidence are put forward.

Firstly, one may suggest that AMPS-based poverty trends are incompatible with those based on official data. To address this possibility, an exercise using official data is conducted. The increase of R18 billion in social grant expenditure between 2000/01 and 2004/05 is equivalent to a per capita annual increase in income of R400 (2000 Rand value). Assuming that grants are not targeted at the poor (although in fact they are, via the means test), the entire income distribution derived from the IES2000 is shifted R400 to the right. As shown in the diagram below, if neutrally distributed the social grant expansion results in a decline in the poverty headcount rate of $5 \%$ between 2000 and 2004 (from 34\% to $29 \%$ ). 
Figure 7: Cumulative distribution functions based on the IES1995

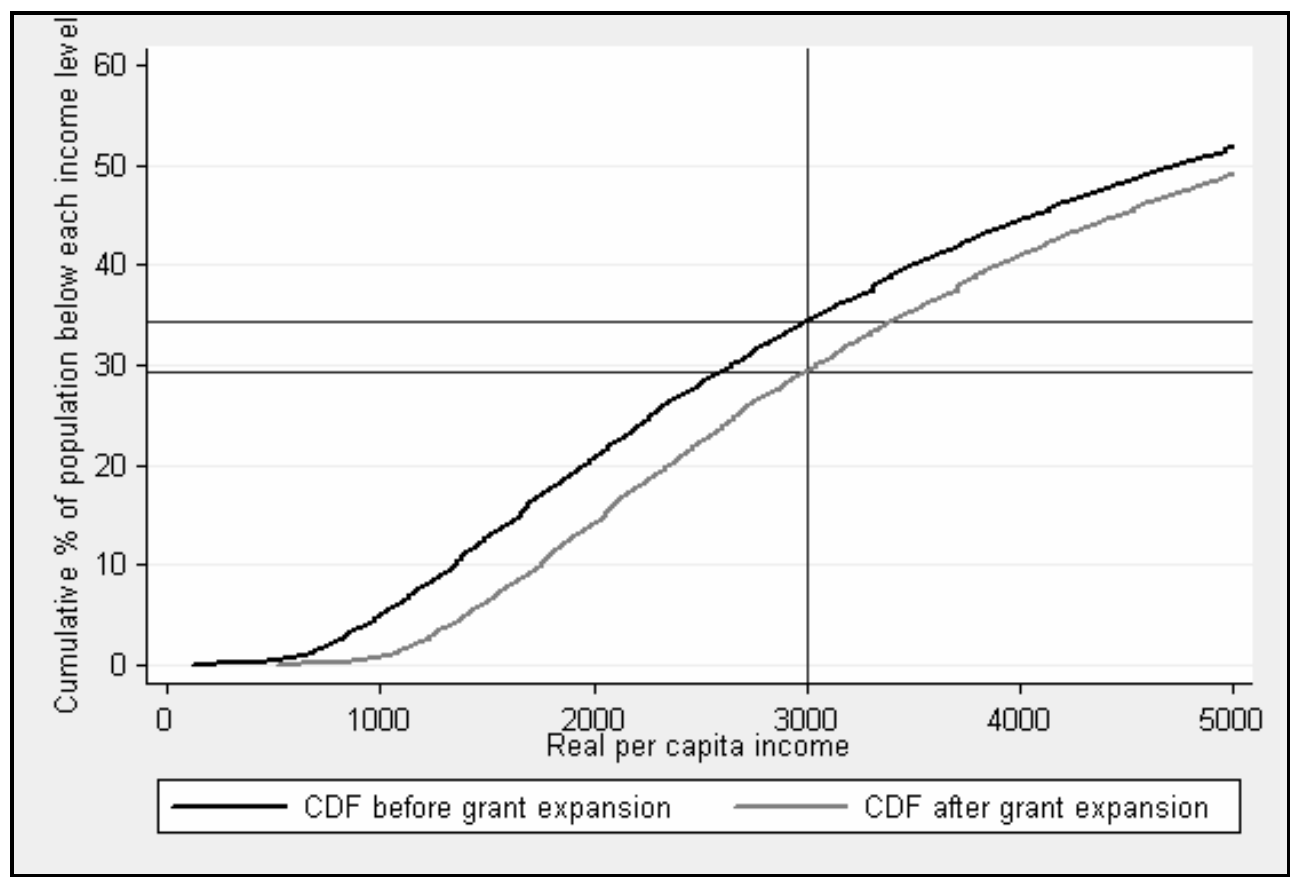

Secondly, as Seekings (2006) points out, data from the GHS surveys show that nutritional outcomes have improved since 2002, the first year in which the GHS was conducted. Amongst households containing children (defined as those aged 17 or under), the proportions of households reporting that a child went hungry during the previous year declined substantially between 2002 and 2005. This is due to a drop in households reporting frequent occurrences of hunger, suggesting that the situation has improved particularly amongst those experiencing the greatest degree of welfare deprivation.

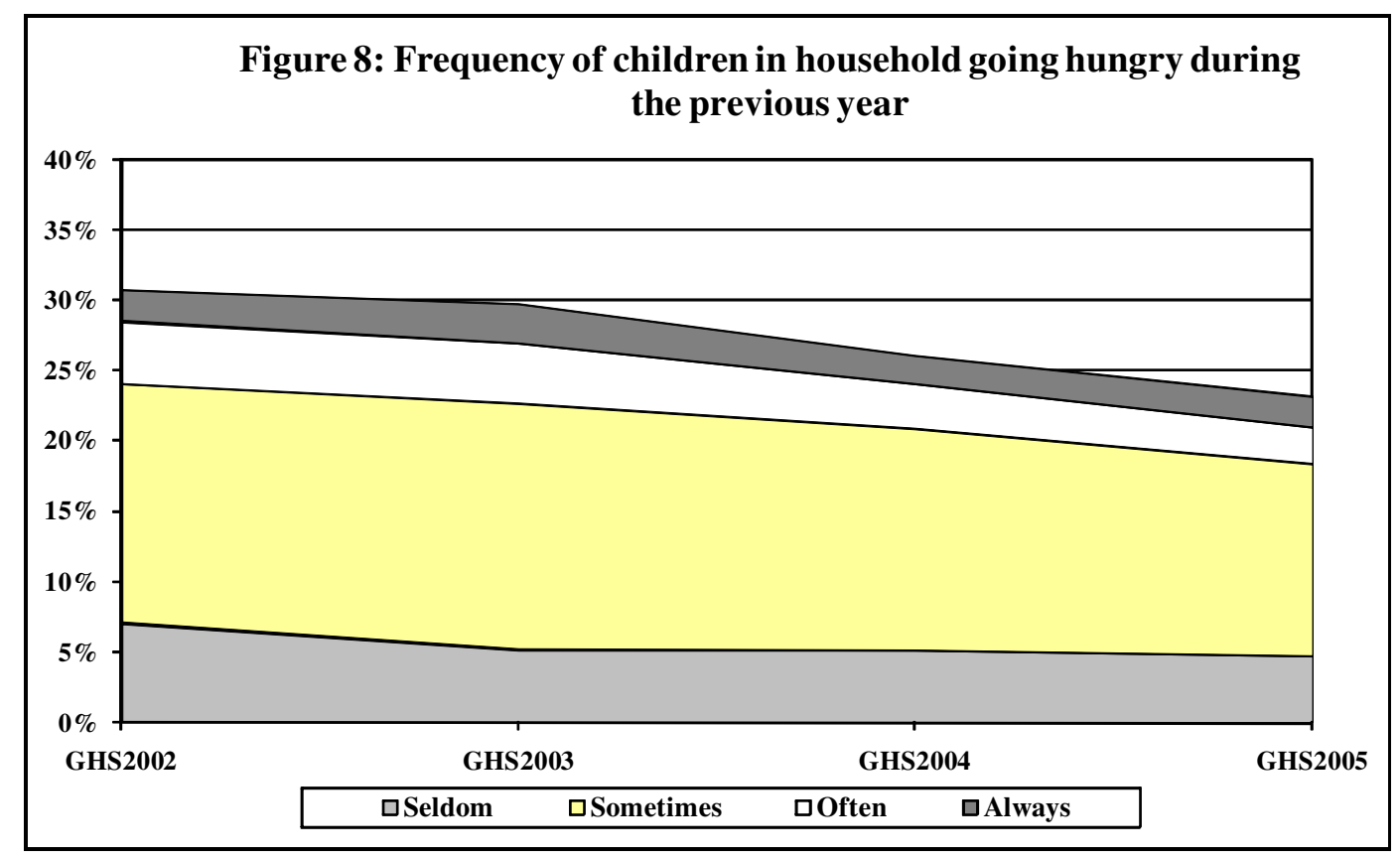


Thirdly, it may be argued more generally that household income and expenditure are poorly captured in surveys, and that analysing such data does reliably capture movement in welfare trends. Further, money metric measures of poverty its many dimensions accurately. To deal with this shortcoming, Bhorat, Naidoo and Van der Westhuizen (2006) use a range of official data sources to track changes in asset poverty (defined to include deprivation of access to basic services) over the period 1993-2004. They find that asset poverty declined over the period, and that asset inequality dropped. This suggests that the welfare of the poor improved in a number of dimensions as a result of government efforts to target poverty through both income (in the form of social grants) and basic service delivery. Those likely to still be suffering the greatest welfare deprivation are the poor in rural areas, particularly remote ones and those comprising former homelands (Burger et al. 2004). In addition to suffering the greatest service delivery backlog burdens (Bhorat et al. 2006), these individuals are least likely to have information on and access to forms of social assistance. Collectively they represent a core contemporary policy challenge to the government, which needs to devise innovative and cost-effective ways of reaching them.

Finally, additional support for a hypothesis of falling poverty is reflected in two recently released preliminary research papers. Meth (2006) analysed data from LFSs and found that poverty had fallen post-2000, although not to the same extent as reflected by AMPS. The work of Agüero et al. (2005) on the third wave of the KwaZuluNatal Income Dynamics survey also supports a conclusion of poverty reduction in recent years. Adopting the Hoogeveen and Özler (2006) poverty line of R322 (2000 Rand value), these authors found that poverty fell amongst households in black and Indian households in KwaZulu-Natal between 1998 and 2004. Further, they find evidence of less downward mobility and chronic poverty over this period than during the first few posttransition years. Finally, their research indicates that social grants do alleviate poverty amongst those who are chronically poor, thus providing evidence of effective targeting.

\section{CONCLUDING REMARKS AND POLICY RECOMMENDATIONS}

Two central conclusions emerge from this paper. The first is that money-metric poverty has declined since the turn of the century, in large part due to a dramatic expansion in social assistance expenditure from 2002 onwards. This improvement is mirrored in access to basic services: in fact, the most rapid decline in asset poverty preceded the later but equally notable fall in income poverty. The individuals on whom poverty reduction policy should arguably focus greatest attention now are those that live in more remote rural areas, located a long distance away from both economic opportunity and government assistance.

In view of the centrality of datasets (and their reliability or otherwise) to this paper, the second conclusion is concerned with official alternatives to AMPS. The AMPS data do not provide a perfect substitute for official data sources, which are generally designed with comprehensive measurement of person or household characteristics in mind. However, the status quo regarding the availability of official datasets for poverty analysis leaves something to be desired. The IESs and Censuses potentially provide comprehensive sources of income and expenditure data, but are collected at relatively long intervals (five or ten years) and generally only become available a few years after collection due to lengthy data capturing processes. The LFS and GHS provide more 
frequently collected and speedily released alternatives. However, the household flap in the LFS was discontinued from 2005 on, eliminating this source of household expenditure data. The GHS retains household expenditure data, but in a small number of intervals (approximately eight). This reduces the usefulness of distributional analysis performed on the GHS, particularly since households are bunched in the lowest few expenditure categories. If official surveys captured household income or expenditure data in a greater number of categories, their suitability for poverty research would be greatly enhanced.

\section{BIBLIOGRAPHY}

AGÜERO, J., M.R. CARTER \& J. MAY. 2005. Poverty and inequality from the first decade of democracy: Evidence from KwaZulu-Natal. Paper prepared for Oxford Centre for Study of African Economies/Stellenbosch University Department of Economics conference on "South African Economic Policy under Democracy: A Ten Year Review", held at Stellenbosch, 28-29 October.

ANC TODAY, 3(30), 1-7 August 2003.

ARDINGTON, C., D. LAM, M. LEIBBRANDT \& M. WELCH. 2005. The sensitivity of estimates of post-apartheid changes in South African poverty and inequality to key data imputations. CSSR Working Paper No. 106. Cape Town: Southern Africa Labour and Development Research Unit, Centre for Social Science Research.

BHORAT, H., P. NAIDOO \& C. VAN DER WESTHUIZEN. 2006. Shifts in non-income welfare in South Africa: 1993-2004. DPRU Working Paper 06/108. Cape Town: Development Policy Research Unit, University of Cape Town.

BURGER, R., S. VAN DER BERG, S. VAN DER WALT. \& D. YU. 2004. Geography as destiny: Considering the spatial dimensions of poverty and deprivation in South Africa. Paper presented to the DPRU/TIPS/Cornell University Conference held at Somerset West, 13-15 October.

DEATON, A., 1997. The analysis of household surveys: a microeconometric approach to development policy. Chapters 1 and 3. Baltimore, Maryland U.S.A.: John Hopkins University Press.

HOOGEVEEN, J.G. \& B. ÖZLER. 2004. Not separate, not equal: Poverty and inequality in post-apartheid South Africa. Mimeo. Washington, D.C.: World Bank.

HOOGEVEEN, J.G. \& B. ÖZLER. 2006. Poverty and inequality in post-apartheid South Africa: 1995-2000. In H. Bhorat \& R. Kanbur (eds), Poverty and policy in post-apartheid South Africa, Cape Town, HSRC, pp. 5994. 
KARSHENAS, M. 2003. Global poverty: National accounts based versus survey based estimates. Development and Change 34(4): 683-712.

LEIBBRANDT, M., J. LEVINSOHN \& J. MCCRARY. 2005. Incomes in South Africa since the fall of apartheid. NBER Working Paper 11384. Cambridge, Mass.: National Bureau for Economic Research.

LEIBBRANDT, M., L. POSWELL, P. NAIDOO \& M. WELCH. 2006. Measuring recent changes in South African inequality and poverty using 1996 and 2001 Census data. In H. Bhorat \& R. Kanbur (eds), Poverty and policy in post-apartheid South Africa, Cape Town, Human Sciences Research Council, pp. 95-142.

METH, C. 2006. Income poverty in 2004: A second engagement with the recent $V$ an der Berg et al figures. Working Paper No. 47. Durban: School of Development Studies, University of KwaZulu-Natal.

METH, C. \& R. DIAS. 2004. Increases in poverty in South Africa, 1999-2002. Development Southern Africa 21(1): 59-85.

NATIONAL TREASURY, REPUBLIC OF SOUTH AFRICA. Various years. Intergovernmental Fiscal Review. Pretoria: Government Printer.

SEEKINGS, J. 2006. Facts, myths and controversies: The measurement and analysis of poverty and inequality after apartheid. Paper presented to the DPRU/TIPS Conference held in Johannesburg, 18-20 October.

SIMKINS, C.E.W. 2004. What happened to the distribution of income in South Africa between 1995 and 2001 ? Unpublished draft. [Online.] Available: www.sarpn.org

STATISTICS SOUTH AFRICA (STATS SA). 2002. Earning and spending in South Africa: Selected findings and comparisons from the income and expenditure surveys of October 1995 and October 2000. Pretoria: Government Printer.

UNDP. 2003. South Africa Human Development Report 2003: The Challenge of Sustainable Development. UNDP South Africa: Oxford University Press.

VAN DER BERG, S., R. BURGER, R.P. BURGER, M. LOUW \& D. YU. 2005. Trends in poverty and inequality since the political transition. Stellenbosch Economics Working Paper 01/2005. Stellenbosch: Bureau for Economic Research / Department of Economics, University of Stellenbosch.

VAN DER BERG, S. \& M. LOUW. 2004. Changing patterns of South African income distribution: Towards time series estimates of distribution and poverty. South African Journal of Economics 72(3): 546-572. 
VERMAAK, C. 2005. Trends in income distribution, inequality and poverty in South Africa, 1995 to 2003. Paper presented at the Biennial Economics Society of South Africa Conference held at Durban, 7-9 September.

WHITEFORD, A. \& D.E. VAN SEVENTER. 2000. South Africa's changing income distribution in the 1990s. Studies in Economics and Econometrics 24(3): 7-30. 